\title{
Quantifying the effect of non-spatial and spatial forest stand structure on rainfall partitioning in mountain forests, Southern China
}

\author{
by Chunxia Liu1 ${ }^{1}$, Yujie Wang ${ }^{1,2}{ }^{*}$, Chao $\mathrm{Ma}^{1,2}$, Yunqi Wang1,2, Huilan Zhang ${ }^{1,2}$, Bo Hu${ }^{1}$
}

\begin{abstract}
Forest stand structure plays an important role in rainfall interception and is a focal point in forest hydrology. Previous studies mainly looked at the effect of non-spatial attributes of stands while a few studies addressed the influence of spatial features. The aim of this study was to quantify the effect of stand structure on rainfall partitioning using diameter, height, leaf area index (LAI), neighbourhood comparison, mingling index and uniform angle index. The results revealed that the average accumulative throughfall, stemflow and interception loss accounted for $72.8 \%-83.2 \%, 0.5 \%-11.3 \%$ and $13.3 \%-26.2 \%$ of total precipitation, respectively, and significant differences existed in rainfall partitioning. The accumulative interception loss was negatively related to uniform angle index (a measure of tree spatial distribution patterns) as stand structure attribute was not available at each rainfall event. The effects of stand structure on throughfall, stemflow and interception loss varies considerably under different rainfall conditions. The LAI was significantly associated with interception loss for heavy rainfalls. The mingling index was negatively related to stemflow; however, significant relationships existed between mingling index, throughfall, and interception loss for light rainfall (drizzle). Significant positive relationships existed between uniform angle index and stemflow, while significant relationships existed for interception loss for light and heavy rainfalls. The results highlight that stand structure in combination with rainfall patterns influence rainfall partitioning.
\end{abstract}

Keywords: rainfall partitioning, LAI, mingling index, uniform angle index, rainfall patterns

\section{RÉSUMÉ}

La structure des peuplements forestiers influence grandement l'interception des précipitations et est au cœur même de l'hydrologie forestière. Les études antérieures ont porté principalement sur l'effet des éléments non spatiaux des peuplements et il y a eu peu de travaux sur l'influence des éléments spatiaux. Cette étude avait pour but de quantifier leffet de la structure du peuplement sur la répartition des eaux de pluie en fonction du diamètre, de la hauteur, de lindice de surface foliaire (LAI), des comparaisons avec les voisins, de l'indice de mélange (mingling index) et de l'indice d’angle uniforme (uniform angle index). Les résultats ont montré que la moyenne cumulée de l'égouttement, du ruissellement le long des troncs et des pertes par interception représentaient respectivement $72,8 \%-83,2 \%, 0,5 \%-11,3 \%$ et $13,3 \%-26,2 \%$ de toute la précipitation et qu'il y avait des différences significatives dans la répartition de l'eau de pluie. La perte cumulée par interception montrait une corrélation négative avec l'indice d’angle uniforme (une mesure de la distribution spatiale des arbres) puisque nous ne disposions pas d'une mesure de la structure du peuplement pour chaque épisode de pluie. L'effet de la structure du peuplement sur légouttement, le ruissellement le long des troncs et les pertes par interception varie considérablement sous différentes conditions de précipitations. Le LAI était étroitement corrélé aux pertes par interception durant les fortes précipitations. Une hausse de l'indice de mélange se traduisait par une diminution du ruissellement le long des troncs; il y avait toutefois une relation significative entre l'indice de mélange, légouttement et la perte par interception lors des épisodes de pluie légère (bruine). On a noté des relations positives entre l'indice d’angle uniforme et le ruissellement sur les troncs et des relations significatives avec la perte par interception pour les précipitations légères et fortes. Les résultats montrent clairement que c’est la structure du peuplement combinée à l'intensité des précipitations qui influence la répartition de la précipitation.

Mots-clés : répartition de leau de pluie, LAI, indice de mélange, indice d’angle uniforme, intensité des précipitations

\footnotetext{
${ }^{1}$ Jinyun Forest Ecosystem Research Station, School of Soil and Water Conservation, Beijing Forestry University, Beijing 100083, PR China

${ }^{2}$ Beijing Engineering Research Center of Soil and Water Conservation, Beijing Forestry University, Beijing 100083, PR China;

${ }^{\star}$ Corresponding author: Yujie Wang E-mail: 396576536@163.com
} 


\section{Introduction}

Rainfall interception is essential in the water cycle and has been a research topic in forest hydrology for many years (Cui et al. 1980; Bosch and Hewlett 1982; Dunkerley 2000; Llorens and Domingo 2007; Tanaka et al. 2017). It may be estimated by determining the difference between total precipitation above the canopy and the sum of throughfall and stemflow (Llorens and Domingo 2007; Liang et al. 2011; Shinohara et al. 2013; Carlyle-Moses et al. 2014). Previous studies have shown that the canopy can intercept as much as 10 to $50 \%$ of the total precipitation (Roth et al. 2007; Carlyle-Moses and Gash 2011). The characteristics of the forest can affect the amount of interception loss (Crockford and Richardson 2000; Xiao et al. 2000; Park and Cameron 2008), and rainfall interception by the canopy depends on the amount and intensity of individual rainfall events (Staelens et al. 2008; Li et al. 2016b). This suggests that the proportion of rainfall separated by canopy interception, throughfall, and stemflow depends to a certain extent on the structure of the forest stand and rainfall patterns.

Rainfall interception is closely related to not only stand structure but meteorological factors (Crockford and Richardson 2000; Xiao et al. 2000; Pérez-Suárez et al. 2014). These factors relate to the amount and intensity of rain, as well as wind speeds, air humidity deficits and net radiation (Xiao et al. 2000; Staelens et al. 2008). Canopy cover, leaf characteristics (area, biomass, morphology), and branch traits (densities, number, lengths) are thought to be key factors dominating canopy water storage capacity (Levia et al. 2015; Li et al. 2016a). Tree height also affects canopy roughness and energy exchange with the atmosphere (Dietz et al. 2006). Basal area has a large impact on throughfall (Ponette-González et al. 2010; Molina and Del Campo 2012; Zimmermann et al. 2013). Stem density (Hölscher et al. 2005) and tree diameter (Li et al. 2015) may be important for stemflow generation. However, it is still difficult to assess the relative importance of stand structure attributes for rainfall partitioning in the canopy. If a single stand characteristic is analyzed separately, there may be conflicting results. For example, some studies found that throughfall decreases with LAI (Ponette-González et al. 2010; Tian et al. 2011; Molina and Del Campo 2012; Li et al. 2015b), while Dietz et al. (2006) and Teale et al. (2014) found that LAI has little influence on throughfall. Furthermore, Dietz et al. (2006) found that diameter and crown extension were significantly correlated to throughfall for rain $>10 \mathrm{~mm} \mathrm{~d}^{-1}$ but not for $<10 \mathrm{~mm} \mathrm{~d}^{-1}$. Peng et al. (2014) found the increased extent of interception loss varies with canopy cover and plant area index and depends on rainfall conditions. The two reports highlight the correlation between the effects of stand structure on rainfall partitioning and rainfall conditions.

Structural characteristics of forest stands may be qualitatively represented by non-spatial parameters such as leaf area and biomass, and branch density and inclination (Crockford and Richardson 2000; Levia et al. 2015). These parameters represent the canopy structure and not the whole stand. In fact, spatial structure of the stand is more complex than that of the canopy and is rarely examined (Gadow and Hui 2002). Some parameters such as the neighbourhood comparison, mingling index, and uniform angle index (Gadow and Hui 2002; Zhao et al. 2012) are commonly used in forest management while rarely used in forest hydrology. These parameters quantitatively represent the spatial structure of the forest but little research has been carried out to study their effects on rainfall partitioning.

The effect of stand structure on rainfall partitioning deserves further study as it is of considerable importance for forest hydrology. In this paper, the effect of stand structure on throughfall, stemflow and rainfall interception are analyzed. The main objectives are to: (a) analyze the non-spatial and spatial structure of nine stands using diameter, height, LAI (leaf area index), neighbourhood comparison, mingling index, and uniform angle index; (b) quantify the partitioning of rainfall into throughfall, stemflow, and interception loss by nine typical forests; and, (c) determine the relationships between stand structure and rainfall partitioning.

\section{Materials and Methods}

The study area was located in the Jinyun Mountain National Nature Reserve ( $106^{\circ} 20^{\prime} 18^{\prime \prime}$ to $106^{\circ} 24^{\prime} 42^{\prime \prime} \mathrm{N}, 29^{\circ} 48^{\prime} 25^{\prime \prime}$ to $29^{\circ} 51^{\prime} 53^{\prime} \mathrm{E}$ ), Chongqing, China. It is a national nature reserve spanning a wide gradient of species diversity and complexity. The total area is $76 \mathrm{~km}^{2}$ with altitudes from 350.0 to 951.5 m.a.s.l. and a humid subtropical monsoon climate with average yearly temperatures of $14.8^{\circ} \mathrm{C}$ and $1360 \mathrm{~mm}$ precipitation mainly between April and October, accounting for $70 \%-80 \%$ of the total annual precipitation. Evergreen broadleaved species, conifers, and moso bamboo (Phyllostachys pubescens Pradelle) are the main forests in this region.

\section{Stand structure measurements}

Nine subtropical stands were selected (Table 1), each square and with an area of $3600 \mathrm{~m}^{2}$. Diameters breast height (DBH) and heights of trees with $\mathrm{DBH}>3 \mathrm{~cm}$ were measured; other trees were too small to affect rainfall interception. The coordinate origin was recorded at the northwest corner of each plot, and vertical and horizontal coordinates of each tree measured within areas at least $5-\mathrm{m}$ from the plot limits to avoid edge effects. Six parameters, mean diameter, mean height, leaf area index (LAI), neighbourhood comparison, mingling index, and uniform angle index were used to analyze the stand structure. The representative diameter and height of the stand were estimated by mean diameters and heights of all trees.

LAI, defined as total leaf area divided by crown projection area, was measured by the LAI-2200 Plant Canopy Analyzer (LICOR Inc., Lincoln, NE, USA). Measurements were made monthly with two LAI-2200 sensors under blue sky conditions (ignoring the sun). A $45^{\circ}$ field of view cap was used. Above-canopy readings ("A" readings) were made automatically in a nearby clearing space where the LAI-2200 sensor was centrally located and at a distance of $3.5 \mathrm{x}$ the height of the trees. The other sensor collected below-canopy readings ("B" readings). A total of eight "B" readings along two perpendicular axes and four per axis were recorded in every plot. The " $\mathrm{A}$ " and " $\mathrm{B}$ " readings were taken into account by means of FV2200 software.

Neighbourhood comparison $\left(U_{i}\right)$ is defined as "the proportion of the $n$ nearest neighbour of a given reference tree which is bigger than the reference tree" (Gadow and Hui 2002) and expressed as: 
Table 1. Basic information of the observation forest stand plots

\begin{tabular}{|c|c|c|c|c|c|}
\hline Forest types & Abbr. & $\begin{array}{l}\text { Exposition and } \\
\text { Inclination }\left(^{\circ}\right)\end{array}$ & $\begin{array}{l}\text { Elevation } \\
(\mathbf{m})\end{array}$ & $\begin{array}{l}\text { Slope } \\
\left({ }^{\circ}\right)\end{array}$ & Main Tree species \\
\hline $\begin{array}{l}\text { mixed broadleaved/ } \\
\text { coniferous forest }\end{array}$ & $C_{1}$ & NW 32.2 & 780 & $23 \sim 28$ & $\begin{array}{l}\text { Pinus massoniana, Symplocos setchuensis, } \\
\text { Gordonia acuminata Chang, Lindera } \\
\text { kwang-tungensis; }\end{array}$ \\
\hline $\begin{array}{l}\text { mixed broadleaved/ } \\
\text { coniferous forest }\end{array}$ & $C_{2}$ & NW 20.9 & 830 & $17 \sim 23$ & $\begin{array}{l}\text { Cunning hamia lanceolata, Castanopsis } \\
\text { fargesiiFranch, Engelhardtia serrata Blume, } \\
\text { Quercus fabri; }\end{array}$ \\
\hline $\begin{array}{l}\text { mixed broadleaved/ } \\
\text { coniferous forest }\end{array}$ & $C_{3}$ & NW 37.6 & 710 & $15 \sim 21$ & $\begin{array}{l}\text { Pinus massoniana, Cunning hamia lanceolata, } \\
\text { Symplocos setchuensis, Gordonia acuminata } \\
\text { Chang, Cinnamomum camphora; }\end{array}$ \\
\hline $\begin{array}{l}\text { evergreen broadleaved } \\
\text { forest }\end{array}$ & $B_{1}$ & NW 31.2 & 830 & $21 \sim 25$ & $\begin{array}{l}\text { Gordonia acuminata Chang, Symplocos } \\
\text { setchuensis, Adinandra bockian; }\end{array}$ \\
\hline $\begin{array}{l}\text { evergreen broadleaved } \\
\text { forest }\end{array}$ & $B_{2}$ & NW 33.2 & 8001 & $5 \sim 18$ & $\begin{array}{l}\text { Castanopsis fargesiiFranch, Castanopsis carlesii } \\
\text { var. spinulosa, Castanopsis carlesii sclerophylla; }\end{array}$ \\
\hline $\begin{array}{l}\text { mixed Moso bamboo/ } \\
\text { coniferous forest }\end{array}$ & $M_{1}$ & NW 35.0 & 860 & $13 \sim 19$ & $\begin{array}{l}\text { Phyllostachys pubescens, Pinus massoniana, } \\
\text { Symplocos setchuensis, Cunning hamia } \\
\text { lanceolata, Gordonia acuminata Chang; }\end{array}$ \\
\hline $\begin{array}{l}\text { mixed Moso bamboo/ } \\
\text { broadleaved forest }\end{array}$ & $M_{2}$ & NW 36.2 & 810 & $16 \sim 22$ & $\begin{array}{l}\text { Phyllostachys pubescens, Cunning hamia } \\
\text { lanceolata, Symplocos setchuensis, Castanopsis } \\
\text { fargesiiFranch, Gordonia acuminata Chang; }\end{array}$ \\
\hline $\begin{array}{l}\text { mixed Moso bamboo/ } \\
\text { broadleaved/coniferous } \\
\text { forest }\end{array}$ & $M_{3}$ & NW 38.9 & 770 & $13 \sim 20$ & $\begin{array}{l}\text { Phyllostachys pubescens, Gordonia acuminata } \\
\text { Chang, Symplocos setchuensis, Lindera } \\
\text { kwang-tungensis, Castanopsis fargesiiFranch; }\end{array}$ \\
\hline $\begin{array}{l}\text { Moso bamboo pure } \\
\text { forests }\end{array}$ & $M$ & NW 37.1 & 720 & $12 \sim 16$ & Phyllostachys pubescens \\
\hline
\end{tabular}

(1) $U_{i}=\frac{1}{4} \sum_{j=1}^{4} k_{j}$

If the neighbour $j$ is smaller than the reference tree $i, k_{j}=$ 0 ; otherwise, $k_{j}=1$. With four neighbours, $U_{i}$ can assume the five values in Fig.la.

The estimator for the neighbourhood comparison of a given forest is $\bar{U}$, the arithmetic mean of all $U_{i}$ values is:

(2) $\bar{U}=\frac{1}{n} \sum_{n=1}^{n} U_{i}$

Where $U_{i}$ is the neighbourhood comparison of the $i$-th reference tree, $n$ is the number of trees.

Mingling index $\left(M_{i}\right)$ is defined as the proportion of the $n$ nearest neighbours that do not belong to the same species (Gadow and Füldner 1992), and is expressed as:

(3) $M_{i}=\frac{1}{4} \sum_{j=1}^{4} V_{j}$
If the neighbour $j$ does not belong to the same species as the reference tree $i, v_{j}=1$; otherwise, $v_{j}=0$. With four neighbours, $M_{i}$ can assume the five values in Fig. $1 \mathrm{~b}$.

The estimator for the mingling index of a given forest is

$\bar{M}$, the arithmetic mean of all $M_{i}$ values is:

$$
\bar{M}=\frac{1}{n} \sum_{n=1}^{n} M_{i}
$$

Where $M_{i}$ is the mingling index of the $i$-th reference tree, $n$ is the number of trees.

Uniform angle index $\left(W_{i}\right)$ is defined as "the fraction of the angles $a_{j}$, which are smaller than the standard angle $\alpha_{0}$ " (Gadow and Hui 2002). In this study, the standard angle $a_{0}$ is $72^{\circ}$ (Zhao et al. 2012). The formula is:

(5) $W_{i}=\frac{1}{4} \sum_{j=1}^{4} z_{j}$

If $a_{j}<a_{0}, z_{j}=1$; otherwise $z_{j}=0$. With four neighbours, there are five possible values that $W_{i}$ can assume (Fig.1c). 

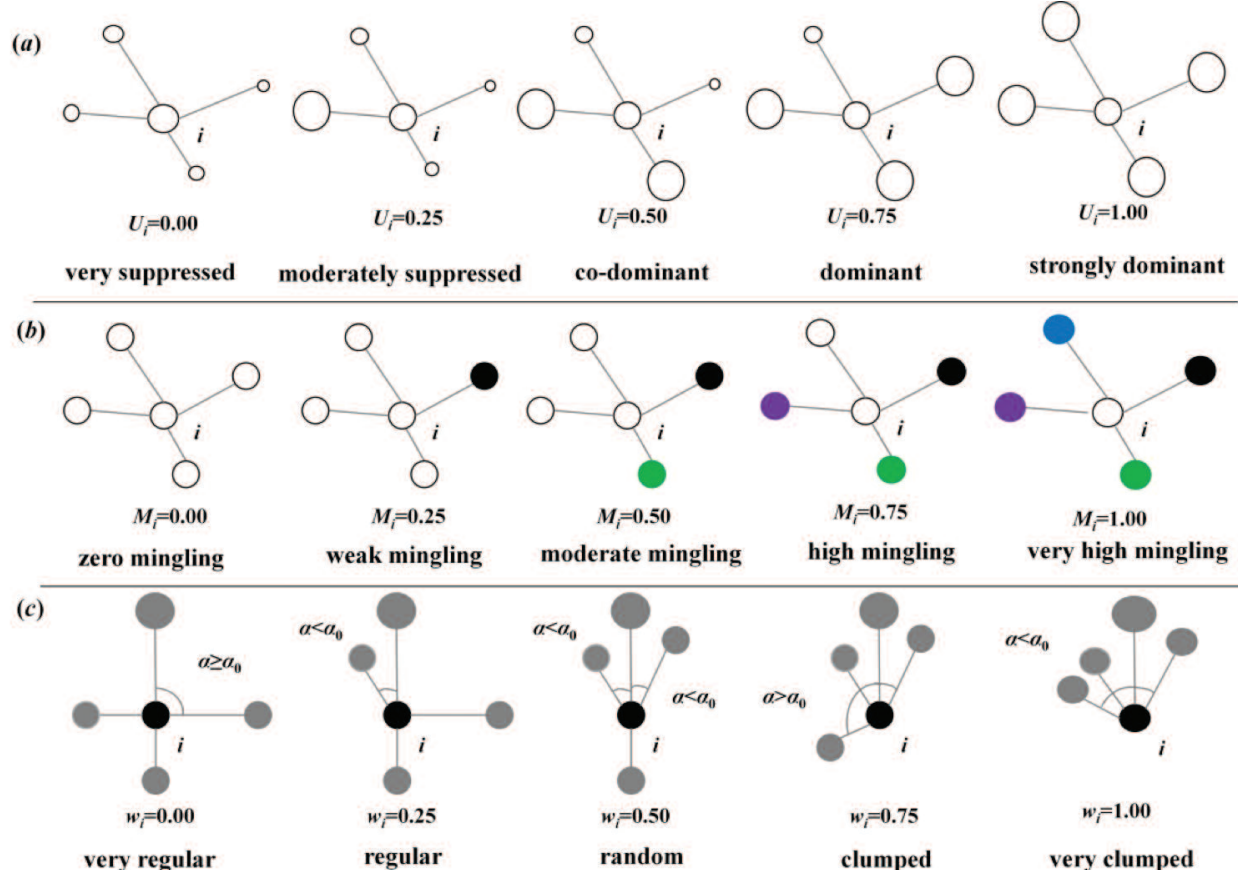

Fig. 1 The meaning for the values of spatial structure parameters. (a) Different size of circles represent different tree sizes; (b) Different colors represent different tree species; (c) $\alpha$ is the angle between the reference tree and its neighbour tree, $\alpha_{0}$ is the standard angle.

Most studies use the mean value $\bar{W}$ to reflect the overall distribution pattern of the stand which is expressed as:

(6) $\bar{W}=\frac{1}{n} \sum_{n=1}^{n} W_{i}$

Where $W_{i}$ is the mingling index of the $i$-th reference tree, $n$ the number of trees. The $\bar{W}$ values fall in the interval $0.475-0.517$, and the distribution pattern tends to be regular. If $\bar{W}$ values are $>0.517$, the distribution pattern tends to clump and $\bar{W}$ values $<0.475$ tend to be random.

Total rainfall, throughfall and stemflow measurements Total rainfall above the canopy from 27 March to 29 October 2013 was measured using a tipping bucket rain gauge $3 \mathrm{~m}$ above the ground and $200 \mathrm{~m}$ from the experimental plots. Measurements were recorded at 10-min intervals.

During the measurement period, 66 rainfall events with a total precipitation of $1085 \mathrm{~mm}$ were recorded (Table 2). The average amount of rain per event was $16.4 \pm 21.2 \mathrm{~mm}$, with a maximum of $81.6 \mathrm{~mm}$ and a minimum of $0.2 \mathrm{~mm}$. The duration of rainfall events varied from 0.2 to $27.5 \mathrm{hr}$, with the average being $10.4 \pm 8.1 \mathrm{~h}$. The average rainfall intensity was $2.0 \pm$ $2.0 \mathrm{~mm} \mathrm{hr}^{-1}$, with a maximum of $10.1 \mathrm{~mm} \mathrm{hr}^{-1}$ and a minimum of $0.1 \mathrm{~mm} \mathrm{hr}^{-1}$.

Throughfall $(T F)$ in each plot was continuously recorded by 25 rain gauges. Among them, $1320-\mathrm{cm}$ diameter and $100-$ $\mathrm{cm}$ high gauges automatically recorded the rainfall by $0.2 \mathrm{~mm}$ per tip. The other 12 homemade rain gauges, $20-\mathrm{cm}$ diameter and $40-\mathrm{cm}$ high, verified the data of the automatic stations. These gauges were spaced evenly over a regular $10 \mathrm{~m} \times 10 \mathrm{~m}$ grid in each plot (Fig. 2a) at fixed locations throughout the study period. The gauges were set up 1-m from tree trunks and $100 \mathrm{~cm}$ above the forest floor to avoid ground splash and understory effects. The tipping buckets provided automatic measurements of throughfall, and data loggers recorded at 10-min intervals. Data from homemade gauges were collected at three to seven days on days with no rain. The reliability of homemade gauges was examined in terms of independent experiments carried out in an open field, where one standard gauge and three homemade gauges were compared over the 66 rainfall events. A linear relationship with a $R^{2}$ of 0.974 was found between the results of standard and homemade gauges (Fig. 2b). Data measured by homemade gauges were corrected according to the linear relationship.

Five diameter classes were defined for each species and a representative tree with a diameter close to the mean value selected. Stemflow $(S F)$ was collected from these trees using plastic tubes cut and surrounding the trunk two to three laps at $1.3 \mathrm{~m}$. These tubes were attached with nails and grouted with glass cement and the ends put into plastic buckets. The water volume was measured at 3- to 7-day intervals on days with no rain, and translated into stemflow $(\mathrm{mm})$ calculated as:

(7) $S F=\frac{1}{M} \sum_{i=1}^{n} \frac{S F_{n}}{K_{n}} M_{n}$ 
Table 2. Rainfall characteristics

\begin{tabular}{|c|c|c|c|c|c|c|c|c|c|}
\hline Event & Date & $\begin{array}{l}\text { Amount } \\
(\mathrm{mm})\end{array}$ & $\begin{array}{c}\text { Duration } \\
\text { (h) }\end{array}$ & $\begin{array}{c}\text { Mean } \\
\text { intensity } \\
\left(\mathrm{mm} \mathrm{h}^{-1}\right)\end{array}$ & Event & Date & $\begin{array}{c}\text { Amount } \\
(\mathrm{mm})\end{array}$ & $\begin{array}{l}\text { Duration } \\
\text { (h) }\end{array}$ & $\begin{array}{c}\text { Mean } \\
\text { intensity } \\
\left(\mathrm{mm} \mathrm{h}^{-1}\right)\end{array}$ \\
\hline 1 & $2013 / 3 / 27$ & 1.0 & 12.50 & 0.08 & 34 & $2013 / 6 / 28$ & 18.4 & 20.33 & 0.90 \\
\hline 2 & $2013 / 4 / 7$ & 0.6 & 3.17 & 0.19 & 35 & $2013 / 6 / 29$ & 12.6 & 5.33 & 2.36 \\
\hline 3 & $2013 / 4 / 9$ & 0.4 & 0.33 & 1.20 & 36 & $2013 / 7 / 1$ & 14.6 & 2.00 & 7.30 \\
\hline 4 & $2013 / 4 / 10$ & 1.8 & 3.67 & 0.49 & 37 & $2013 / 7 / 3$ & 9.8 & 8.83 & 1.11 \\
\hline 5 & $2013 / 4 / 12$ & 11.4 & 15.00 & 0.76 & 38 & $2013 / 7 / 4$ & 28.4 & 12.83 & 2.21 \\
\hline 6 & $2013 / 4 / 16$ & 0.2 & 0.17 & 1.20 & 39 & $2013 / 7 / 12$ & 41.2 & 20.00 & 2.06 \\
\hline 7 & $2013 / 4 / 17$ & 3.4 & 5.50 & 0.62 & 40 & $2013 / 7 / 13$ & 5.9 & 12.00 & 0.49 \\
\hline 8 & $2013 / 4 / 18$ & 0.6 & 2.83 & 0.21 & 41 & $2013 / 7 / 23$ & 2.2 & 0.67 & 3.30 \\
\hline 9 & $2013 / 4 / 20$ & 16.2 & 8.83 & 1.83 & 42 & $2013 / 7 / 25$ & 10.1 & 6.50 & 1.55 \\
\hline 10 & $2013 / 4 / 24$ & 0.2 & 0.17 & 1.20 & 43 & $2013 / 7 / 28$ & 10.3 & 13.83 & 0.74 \\
\hline 11 & $2013 / 4 / 25$ & 5.4 & 2.17 & 2.49 & 44 & $2013 / 7 / 31$ & 3.8 & 18.00 & 0.21 \\
\hline 12 & $2013 / 4 / 28$ & 15.0 & 5.17 & 2.90 & 45 & $2013 / 8 / 6$ & 72.2 & 23.00 & 3.14 \\
\hline 13 & $2013 / 4 / 29$ & 7.6 & 12.00 & 0.63 & 46 & $2013 / 8 / 7$ & 34.7 & 20.33 & 1.70 \\
\hline 14 & $2013 / 4 / 30$ & 7.0 & 0.83 & 8.40 & 47 & $2013 / 8 / 10$ & 1.5 & 2.00 & 0.74 \\
\hline 15 & $2013 / 5 / 1$ & 5.0 & 7.00 & 0.71 & 48 & $2013 / 8 / 23$ & 77.4 & 27.50 & 2.81 \\
\hline 16 & $2013 / 5 / 6$ & 13.8 & 2.33 & 5.91 & 49 & $2013 / 8 / 24$ & 3.6 & 1.00 & 3.60 \\
\hline 17 & $2013 / 5 / 8$ & 25.2 & 16.33 & 1.54 & 50 & $2013 / 8 / 25$ & 13.4 & 2.33 & 5.74 \\
\hline 18 & $2013 / 5 / 10$ & 40.2 & 13.67 & 2.94 & 51 & $2013 / 8 / 26$ & 0.6 & 0.67 & 0.90 \\
\hline 19 & $2013 / 5 / 12$ & 16.0 & 20.00 & 0.80 & 52 & $2013 / 8 / 28$ & 1.4 & 1.00 & 1.40 \\
\hline 20 & $2013 / 5 / 14$ & 12.0 & 6.17 & 1.95 & 53 & $2013 / 8 / 29$ & 15.2 & 1.50 & 10.13 \\
\hline 21 & $2013 / 5 / 21$ & 75.8 & 18.67 & 4.06 & 54 & $2013 / 8 / 30$ & 40.0 & 24.00 & 1.67 \\
\hline 22 & $2013 / 5 / 22$ & 29.4 & 20.50 & 1.43 & 55 & $2013 / 8 / 31$ & 77.4 & 19.33 & 4.00 \\
\hline 23 & $2013 / 5 / 23$ & 4.8 & 13.33 & 0.36 & 56 & 2013/9/1 & 3.6 & 19.83 & 0.18 \\
\hline 24 & $2013 / 5 / 24$ & 25.0 & 20.67 & 1.21 & 57 & $2013 / 9 / 12$ & 0.6 & 1.00 & 0.60 \\
\hline 25 & $2013 / 5 / 25$ & 14.0 & 17.67 & 0.79 & 58 & $2013 / 9 / 23$ & 0.6 & 4.67 & 0.13 \\
\hline 26 & $2013 / 5 / 28$ & 5.0 & 12.00 & 0.42 & 59 & $2013 / 9 / 24$ & 0.2 & 0.17 & 1.20 \\
\hline 27 & $2013 / 5 / 29$ & 55.6 & 10.00 & 5.56 & 60 & $2013 / 9 / 30$ & 45.0 & 22.83 & 1.97 \\
\hline 28 & $2013 / 6 / 1$ & 12.0 & 3.67 & 3.27 & 61 & $2013 / 10 / 3$ & 4.8 & 22.17 & 0.22 \\
\hline 29 & $2013 / 6 / 7$ & 2.4 & 0.67 & 3.60 & 62 & $2013 / 10 / 5$ & 1.2 & 7.67 & 0.16 \\
\hline 30 & $2013 / 6 / 14$ & 3.0 & 18.00 & 0.17 & 63 & $2013 / 10 / 6$ & 7.0 & 10.67 & 0.66 \\
\hline 31 & $2013 / 6 / 24$ & 81.6 & 23.00 & 3.55 & 64 & $2013 / 10 / 9$ & 4.8 & 16.67 & 0.29 \\
\hline 32 & $2013 / 6 / 25$ & 13.2 & 6.50 & 2.03 & 65 & $2013 / 10 / 10$ & 4.8 & 22.17 & 0.22 \\
\hline 33 & $2013 / 6 / 27$ & 10.6 & 13.83 & 0.77 & 66 & $2013 / 10 / 24$ & 2.5 & 0.83 & 3.02 \\
\hline
\end{tabular}

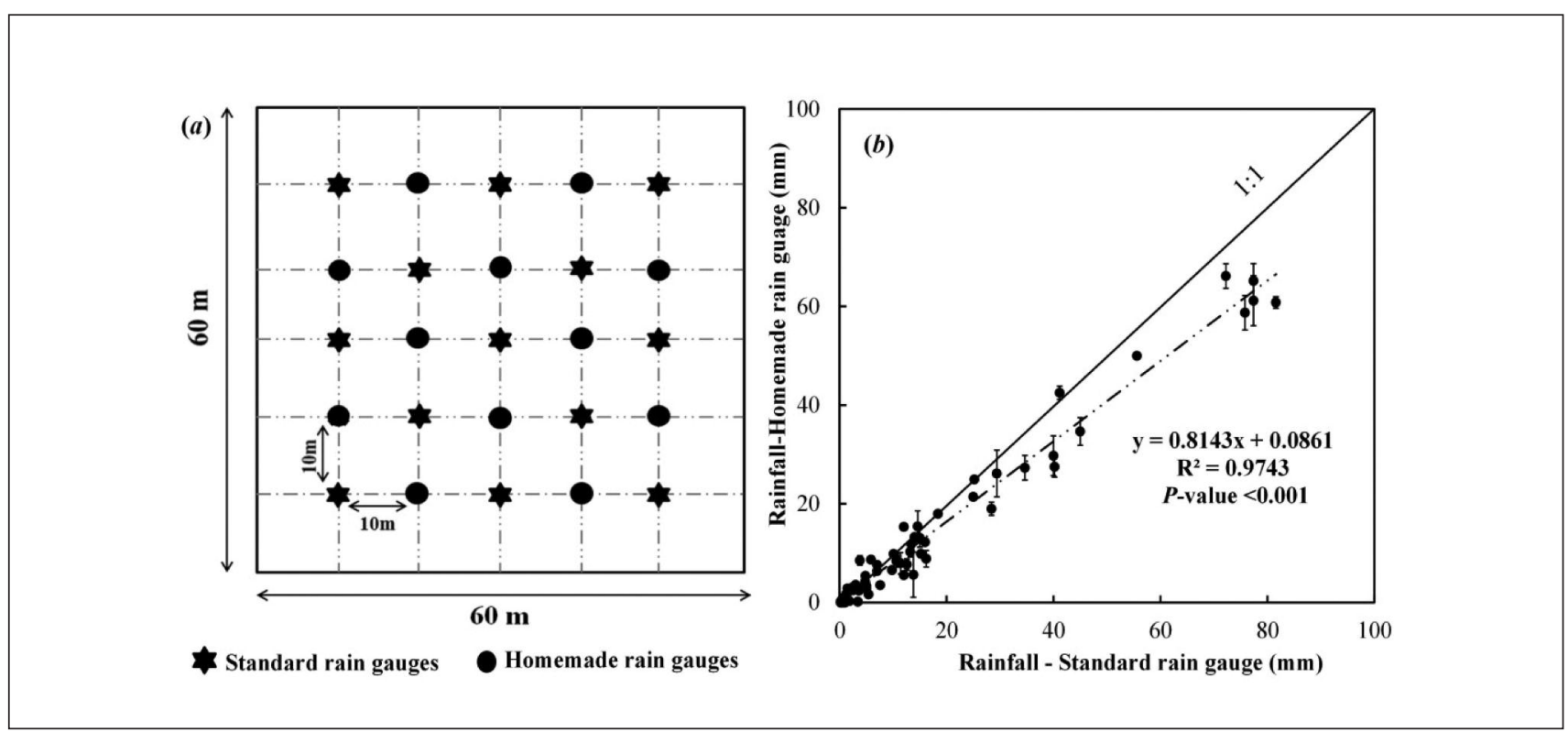

Fig.2 Spatial distribution of the throughfall gauges in each area and regression analyses of the rainfall between standard and homemade rain gauges. 
Where $S F$ is stemflow volume $(\mathrm{mm}), M$ is the number of trees per unit area (trees $/ \mathrm{m}^{2}$ ), $S F_{n}$ the stemflow of the sample tree in each diameter class, $n$ the number of trees in the diameter class, $K_{n}$ the average projection area of the sample tree $\left(\mathrm{m}^{2}\right)$, and $M_{n}^{n}$ the number of trees in the diameter class.

\section{Statistical analysis}

Throughfall data was analyzed using the accumulative percent $T F$ which is the average of 25 rain gauges in each plot. The spatial variability of throughfall (Zimmermann et al. 2007) in each stand was measured by the coefficient of variation $(C V)$ :

\section{(8) $C V=\sigma / \mu$}

Where $\sigma$ is the standard deviation of TF gauge volumes, $\mu$ the mean value of TF gauge volumes.

Differences in the accumulative throughfall, stemflow and interception loss among the nine stands were analyzed with a one-way analysis of variance (ANOVA) and the Fisher LSD (Least Significant Difference) test.

The relationships between rainfall interception (dependent variable) and stand structure (independent variable) were investigated through linear regression. The accumulative interception loss was taken as the single dependent variable; total precipitation was classified into four groups to assess correlations between rainfall partitioning: Class I (drizzle, rainfall -10.0 mm); Class II (moderate, rainfall 10.0-25.0 $\mathrm{mm}$ ); Class III (heavy, rainfall 25.0-50.0 mm); and, Class IV (rainstorm, rainfall $>50.0 \mathrm{~mm}$. A significance level of $p \leq 0.05$ was used for all analyses which were performed with the statistical SPSS 20.0 program (SPSS, Chicago, Illinois, USA) and Excel 2010.

\section{Results}

Stand structure characteristics

Table 3 shows the six structural parameters of the stands. Mean diameters were $7.2( \pm 3.6)-12.2( \pm 4.1) \mathrm{cm}$; mean heights varied from $9.0 \pm 2.4 \mathrm{~m}$ to $14.4 \pm 3.3 \mathrm{~m}$. Average LAIs were $1.7( \pm 0.7)-3.9( \pm 1.4)$, indicating that the mixed broadleaved-coniferous forests have the highest LAI.

The neighbourhood comparisons of most stands were approximately 0.5 , illustrating that they are in a co-dominant state. The $M_{1}$ stand is in a partial to a moderately suppressed

Table 3. Stand structure parameters in the study forest stands. LAl=leaf area index, $U=$ neighbourhood comparison, $M=$ mingling index, $W=$ uniform angle index, $S D=$ standard deviation

\begin{tabular}{|c|c|c|c|c|c|c|c|c|c|}
\hline \multirow{2}{*}{$\begin{array}{l}\text { Forest } \\
\text { types }\end{array}$} & \multicolumn{2}{|c|}{ DBH (cm) } & \multicolumn{2}{|c|}{ Height (m) } & \multicolumn{2}{|c|}{$L A I\left(\mathrm{~m}^{2} \mathrm{~m}^{-2}\right)$} & \multirow[b]{2}{*}{$U$} & \multirow[b]{2}{*}{$M$} & \multirow[b]{2}{*}{$\boldsymbol{W}$} \\
\hline & Mean & SD & Mean & SD & Mean & SD & & & \\
\hline$C_{1}$ & 11.2 & 4.1 & 12.6 & 3.0 & 3.9 & 1.4 & 0.52 & 0.82 & 0.485 \\
\hline$C_{2}$ & 10.2 & 2.8 & 9.0 & 2.4 & 3.2 & 0.9 & 0.43 & 0.65 & 0.519 \\
\hline$C_{3}^{2}$ & 11.1 & 5.3 & 9.7 & 3.8 & 2.8 & 1.3 & 0.42 & 0.79 & 0.499 \\
\hline$B_{1}^{3}$ & 10.5 & 4.0 & 10.8 & 3.1 & 2.4 & 1.2 & 0.47 & 0.6 & 0.523 \\
\hline$B_{2}$ & 12.2 & 4.1 & 10.4 & 3.1 & 2.2 & 1.6 & 0.45 & 0.73 & 0.517 \\
\hline$\stackrel{2}{M}_{1}$ & 10.6 & 3.7 & 9.4 & 2.2 & 1.7 & 0.7 & 0.35 & 0.57 & 0.526 \\
\hline$M_{2}^{1}$ & 11.4 & 3.1 & 9.2 & 2.4 & 2.7 & 0.9 & 0.47 & 0.48 & 0.533 \\
\hline$M_{3}^{2}$ & 7.2 & 3.6 & 11.8 & 2.8 & 3.4 & 1.3 & 0.65 & 0.57 & 0.529 \\
\hline$M^{3}$ & 10.0 & 1.5 & 14.4 & 3.3 & 2.1 & 1.8 & 0.52 & 0 & 0.548 \\
\hline
\end{tabular}

state (0.35) and the $\mathrm{M}_{3}$ stand is almost in a dominant state (0.65). Pure moso bamboo forest illustrates zero mingling, and $M_{1}, M_{2}$, and $M_{3}$ stands each have the lowest mingling index of 0.5 , suggesting that they tend to be moderate mingling. The mingling index of mixed forest $\mathrm{C}_{2}$ and evergreen broadleaved forests $B_{1}$ and $B_{2}$ are between moderate and high mingling. Meanwhile, $\mathrm{C}_{1}$ and $\mathrm{C}_{3}$ with the highest mingling index $(>0.75)$ are between high and very high mingling. The uniform angles index of $\mathrm{C}_{1}, \mathrm{C}_{3}$, and $\mathrm{B}_{2}$ fall in the interval [0.475-0.517], suggesting that the distribution pattern tends to be random. The uniform angle index of $C_{2}, B_{1}, M_{1}, M_{2}, M_{3}$, and $\mathrm{M}$ is $>0.517$, indicating that the distribution pattern of these stands tend to be clumped.

\section{Throughfall, stemflow and interception loss}

During the measurement period, 66 rainfall events with a total precipitation of $1085.1 \mathrm{~mm}$ occurred. The average amount of rain per event was $16.4 \pm 11.4 \mathrm{~mm}$, with a maximum of $81.6 \mathrm{~mm}$ and a minimum of $0.2 \mathrm{~mm}$. The total accumulative throughfall, stemflow and interception loss percentages in rainfall partitioning of the nine stands are presented in Fig. 3. Significant differences exist among most stands $(p<$ $0.05)$. The total accumulative throughfall percentages are in the range of $72.8 \%-83.2 \%$. The $\mathrm{C}_{2}, \mathrm{~B}_{2}$ and $\mathrm{M}_{1}$ stands have significantly higher throughfall compared to the others; no significant differences exist among the three stands. Moreover, no significant differences were found between $C_{3}$ and $M_{3}$, and among $\mathrm{C}_{1}, \mathrm{~B}_{1}, \mathrm{M}_{2}$ and $\mathrm{M}$. The total stemflow ranges from $0.5 \%$ to $11.3 \%$. The pure moso bamboo forest $(\mathrm{M})$ has the highest stemflow compared to the other forest types, followed by mixed bamboo forests, and evergreen broad-leaved forest $\left(M_{1}, M_{2}\right.$ and $\left.M_{3}\right)$. There were no significant differences among the three stands. The average accumulative interception losses range from $13.3 \%$ to $26.2 \%$, with a decreasing order of $C_{1}>B_{1}>C_{3}>M_{2}>B_{2}>M_{3}>C_{2}>M_{1}>M$. The $C_{1}$ and $B_{1}$ stands had significantly higher interception losses $(26.2 \%$ and $24.9 \%$, respectively) compared to the other stands, while $\mathrm{M}$ had the lowest at $13.3 \%$. In addition, no significant differences exist between stands $C_{1}$ and $B_{1}, C_{2}$ and $M_{1}, B_{2}$ and $M_{2}, B_{2}$ and $M_{3}$, and $M_{1}$ and $M$.

\section{Effect of stand structure on rainfall interception}

Linear regressions between the average accumulated interception loss percentage and stand structure parameters are showed in Fig. 4. A significant negative correlation exists between interception loss and uniform angle index (Fig. 4f). Although no statistically significant relationships exist between the accumulated interception loss and the other parameters, interception loss increases with LAI and the mingling index (Fig. 4c and Fig. 4e).

Rainfall $0-10.0 \mathrm{~mm}$ and $10.0-25.0 \mathrm{~mm}$ accounted for $51.5 \%$ and $25.8 \%$ of the total number of rainfall 


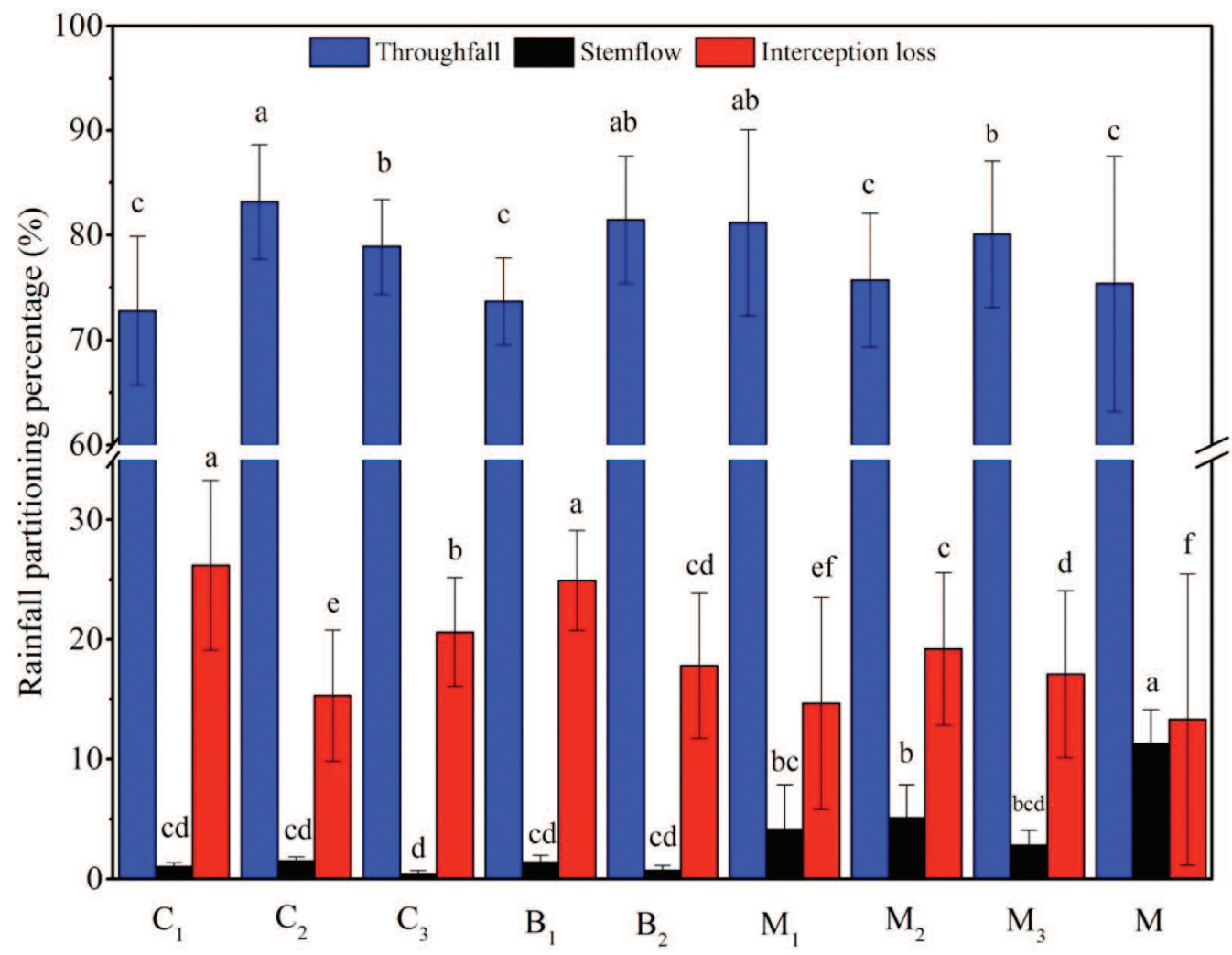

Forest type

Fig. 3 Percentage of the total accumulative throughfall, stemflow and interception loss in the nine stands. Bars with same letters are not significantly different according to the Fisher LSD at $p<0.05$.
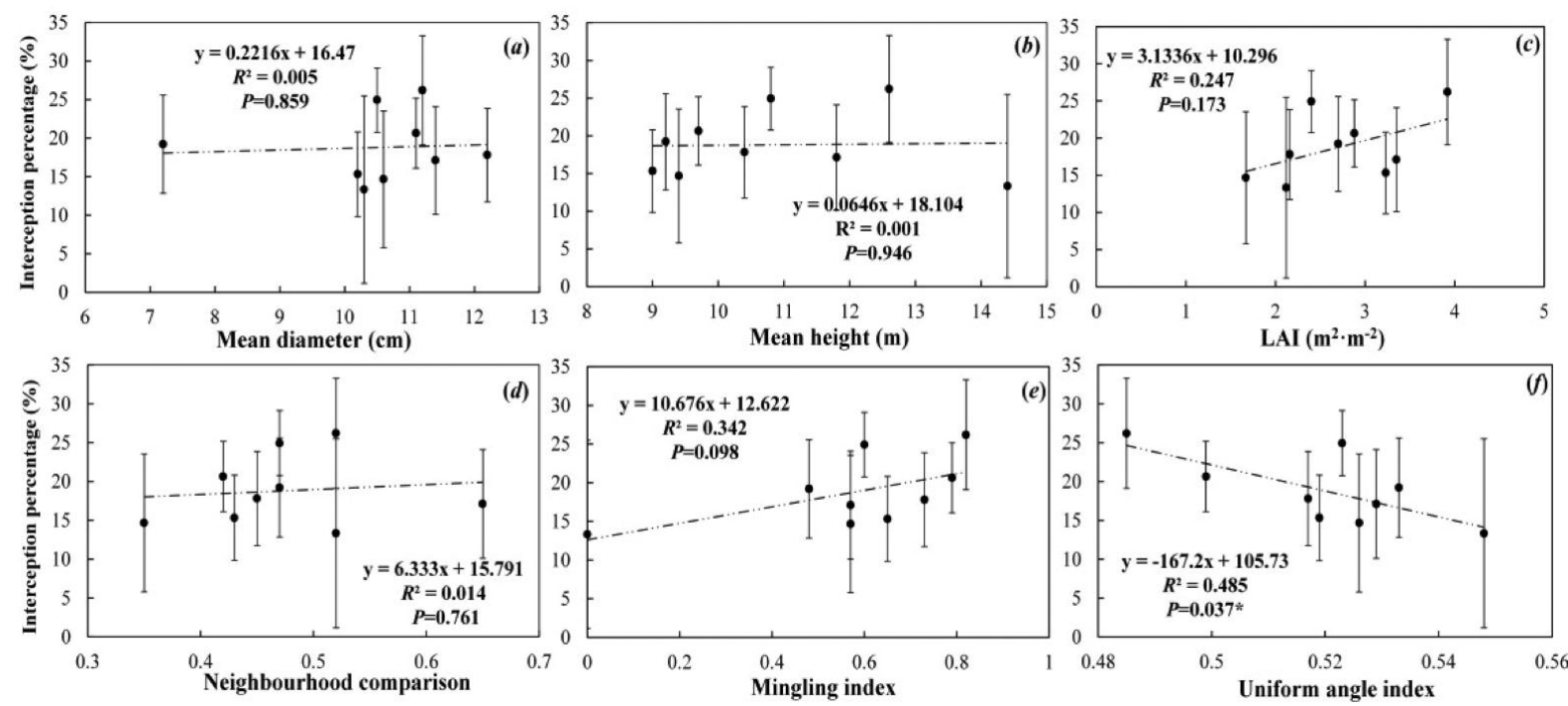

Fig. 4 Correlations between average total accumulative interception loss (\%) and stand structure parameters. 
events, respectively. Rain $>50.0 \mathrm{~mm}$ accounted for $9.1 \%$, but the cumulative amount was the most (40.5\%) (Table 4).

The uniform angle index was negatively correlated to interception loss which may be due to limited canopy water storage. Rainfall events were classified into four groups to further analyze possible correlations (Fig. 5). No significant relationships or tendencies existed between rainfall partitioning and average tree diameter and height. For all rainfall classes, there were no significant relationships between throughfall, stemflow and LAI (Fig. 5a-1 and Fig. 5a-2). Positive correlations exist between the interception loss and LAI for Class III rainfall (heavy; 25.0-50.0 $\mathrm{mm}$ ) and Class IV rainfall (rainstorm; $-50.0 \mathrm{~mm}$ ) (Fig. 5a-3).

Although there were no strong relationships between neighbourhood comparisons and rainfall partitioning, throughfall decreased while interception loss increased with neighbourhood comparison for Class II rainfall (moderate; 10.0-25.0 mm) (Fig. 5b-1 and Fig. 5b-3). The mingling index was significantly related to throughfall and interception loss for Class I rainfall (drizzle; $-10.0 \mathrm{~mm}$ ). As the mingling index increased, throughfall decreased while interception loss increased. The mingling index was negatively correlated to stemflow for all rainfall classes, with $R^{2}>0.9$ (Fig. 5c-2). This indicates that the more complex the forest stand, the less rain reaches the ground and stemflow accumulates. Additionally, no significant relationship was found between throughfall and uniform angle index for all rainfall groups (Fig. 5d-1, Fig. 5d-2). For interception loss, significant relationships exist only for Class I (drizzle) and Class IV (rainstorm) (Fig. 5d-3).

\section{Discussion}

Forest canopies usually present considerable heterogeneity, resulting in a highly variable spatial distribution of throughfall (Rodrigo and Âvila 2001). Studies have determined that errors of $5.0 \%$ or $10.0 \%$ can be acceptable (Rodrigo and Àvila 2001; Carlyle-Moses et al. 2004). In our study, the 25 gauges were evenly spaced in a regular $10 \times 10 \mathrm{~m}$ grid to reduce potential errors caused by spatial variability (Fig. 2a). The errors of the accumulative throughfall for 25 gauges in each stand are less than $10.0 \%$, and a lower $C V$ ranges from 0.05 to 0.07 (Fig. 6). This indicates that the array and number of rain gauges in this study are suitable for representing throughfall.

\section{Comparison of the proportion of throughfall and stemflow to total precipitation}

Throughfall accounts for $72.8 \%-83.2 \%$ of the total precipitation for the nine stands. The proportions are in the ranges reported in the literature, e.g., 60.0\%-95.0\% (Crockford and Richardson 2000; Staelens et al. 2006; Zimmermann et al. 2007). The proportion of throughfall in evergreen broadleaved forests ( $73.6 \%$ to $81.5 \%$ ) is slightly higher than that observed in an evergreen forest in New Zealand where throughfall was approximately 63.0\%-76.0\% (Rowe 1983), while throughfall proportions of mixed forests are similar to those reported by Loustau et al. (1992) and Dolman (1987). The throughfall proportions measured in pure moso bamboo forests is approximately $10 \%$ lower than those documented by Shinohara et al. (2013) and Inoue et al. (2017).

Compared to throughfall, stemflow is a small component of the total precipitation. In this study, stemflow varied from $0.5 \%$ to $11.3 \%$. Proportions measured in mixed broadleaved-
Table 4. Number and frequency of storms by rainfall classes during the study period

\begin{tabular}{lccccc}
\hline & $\begin{array}{c}\text { Rainfall } \\
\text { amount } \\
\text { Class }\end{array}$ & $\begin{array}{c}\text { Number } \\
\text { of } \\
\text { of })\end{array}$ & $\begin{array}{c}\text { Frequency } \\
\text { storms }\end{array}$ & $\begin{array}{c}\text { Cumulative } \\
\text { amount } \\
(\mathbf{m m})\end{array}$ & $\begin{array}{c}\text { Accounting } \\
\text { for total (\%) }\end{array}$ \\
\hline I & $0.00-10.00$ & 34 & 51.52 & 107.3 & 9.89 \\
II & $10.00-25.00$ & 17 & 25.76 & 228.8 & 21.09 \\
III & $25.00-50.00$ & 9 & 13.64 & 309 & 28.48 \\
IV & $>50.00$ & 6 & 9.09 & 440 & 40.55 \\
\hline
\end{tabular}

Notes: I, II, III, IV represents drizzle rainfall, moderate rainfall, heavy rainfall, rainstorm, respectively.

coniferous and evergreen broadleaved forests are between $0.5 \%$ and $1.5 \%$, while mixed moso bamboo forests have higher stemflow values of $2.8 \%-5.1 \%$. These proportions agree with the findings of Levia and Frost (2003) who suggested that stemflow generally represents less than $10 \%$ of the total precipitation. Pure moso bamboo forests have the highest values of $11.3 \%$. This is similar to the study by Shinohara et al. (2013) who estimated the stemflow at $15.2 \%$ in a pure bamboo forest of similar stem density. Our value is higher than that observed in a pure bamboo forest in Kumamoto, Japan where stemflow was $5.0 \%$ of the total precipitation (Inoue et al. 2017), which may be due to lower stem density.

\section{Effect of stand structure on rainfall interception}

There was no evidence of a statistically significant correlation between rainfall partitioning and average tree diameter and height in all rainfall classes. This suggests that the spatially averaged structure characteristics are insufficient for characterizing rainfall partitioning variations. Although no significant relationships were found for throughfall and stemflow with LAI in all rainfall classes, a positive correlation existed between interception loss and LAI for heavy rainfalls and storms $>25.0 \mathrm{~mm}$. This could be attributed to limited canopy storage capacity for a specific forest stand. The majority of rain was intercepted by the canopy when the amount was less than the storage capacity, resulting in smaller differences in interception loss among stands. The percent interception loss with total rainfall forms a power law equation. In Fig. 7, our data indicates the threshold value was about $25.0 \mathrm{~mm}$ for the nine stands. The canopy storage capacity is largely dependent on leaf area index (LAI) which may explain why LAI plays a significant role on interception loss for rainfall $>25.0 \mathrm{~mm}$.

Neighbourhood comparisons had no significant correlation with rainfall partitioning regardless of the size of the rainfall event. As the average neighbourhood comparisons of most forest stands was 0.5 , there were no significant differences (Table 3). Nevertheless, throughfall decreased while interception loss increased with neighbourhood comparisons for moderate rainfall $(10.0-25.0 \mathrm{~mm})$. Higher neighbourhood comparisons resulted in greater dimension and superposition of leaves and branches which intercepted more rain and reduced the throughfall amount.

The mingling index played a significantly negative role on stemflow for all rainfall classes. Higher indices resulted in lower stemflow because stands with greater heterogeneity and a greater superposition of branches intercept a large proportion of stemflow and obstruct stemflow paths. This can lead 


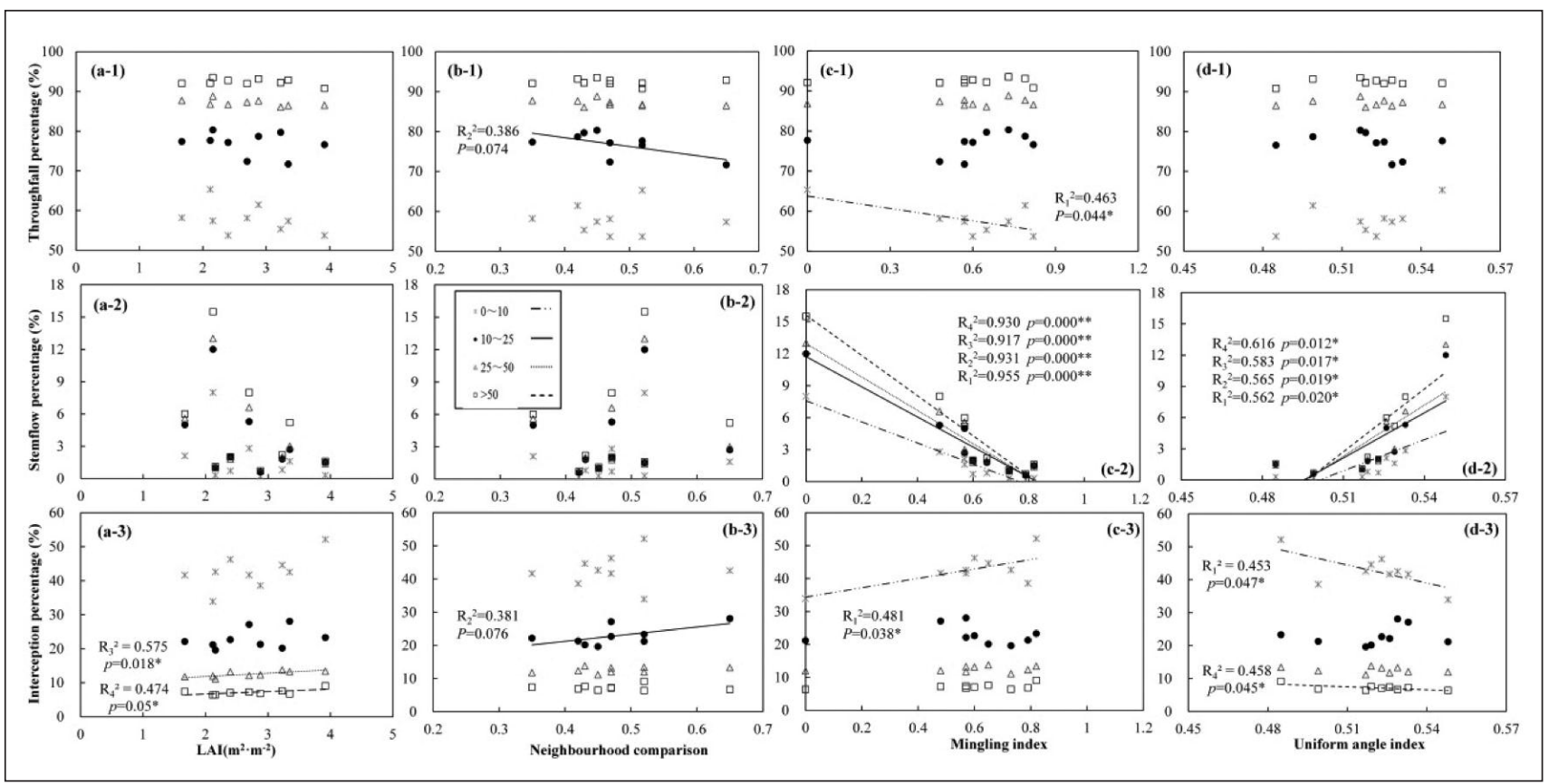

Fig. 5 Correlations between rainfall partitioning (\%) and stand structure parameters under different rainfall classes. ${ }^{*}$ Significant level $p$ $<0.05 \%$ Significant level $p<0.01$.

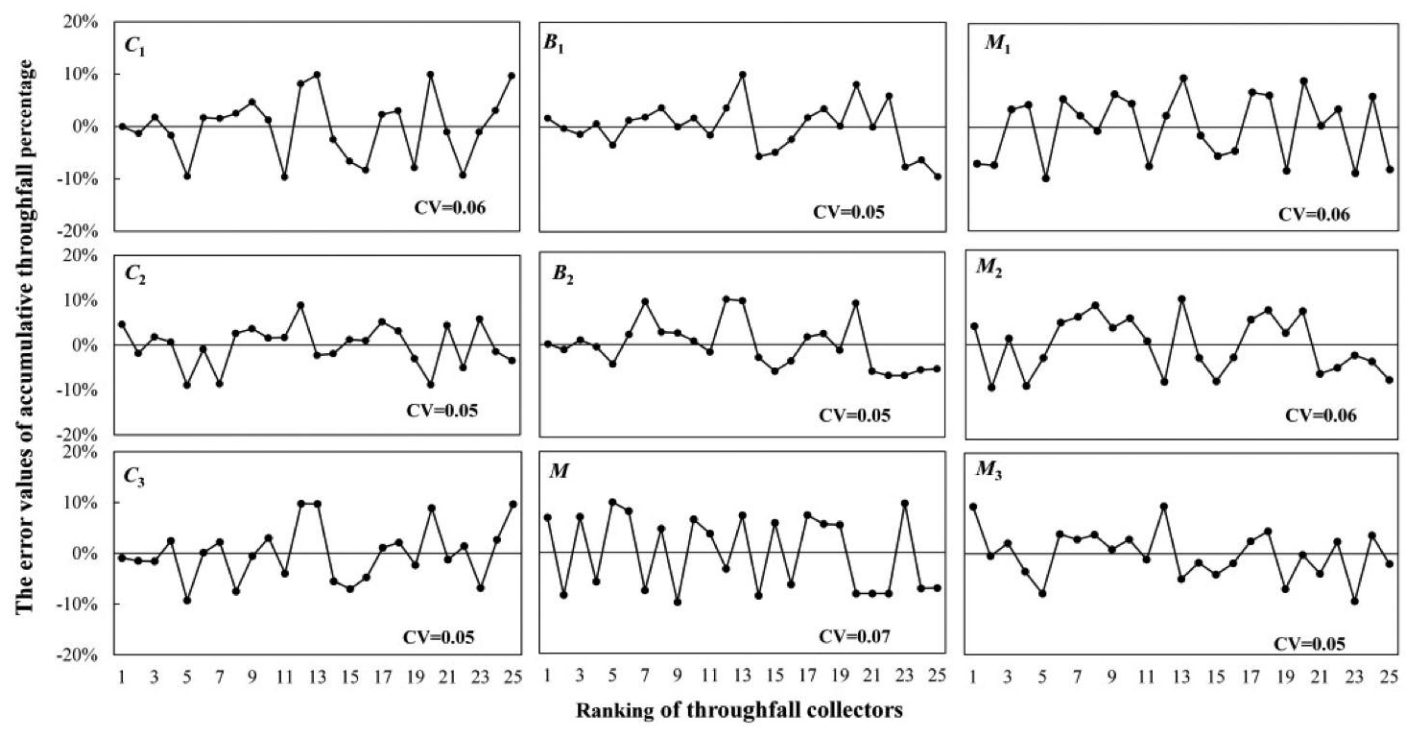

Fig. 6 Variation of accumulative TF (\%) based on 66 rainfall events in the nine stands.

to a decrease in the stemflow mingling index. The close relationship between throughfall, interception loss and the mingling index for Class I rainfall (drizzle) could be because free throughfall is dominant in small rainfall events, while released throughfall is dominant in an intensive rainfall. As the mingling index does not represent the amount or area of leaves and branches, its potential to explain variations in throughfall is limited.
The uniform angle index is positively related to stemflow for all rainfall classes. Larger uniform angle indices result in larger gaps, providing greater direct access for rainwater flowing to the trunk (Crockford and Richardson 2000). In this study, no significant statistical relationships were found between throughfall and uniform angle index, whereas an increasing trend was found. As throughfall increases, significant relationships exist between uniform angle index and 


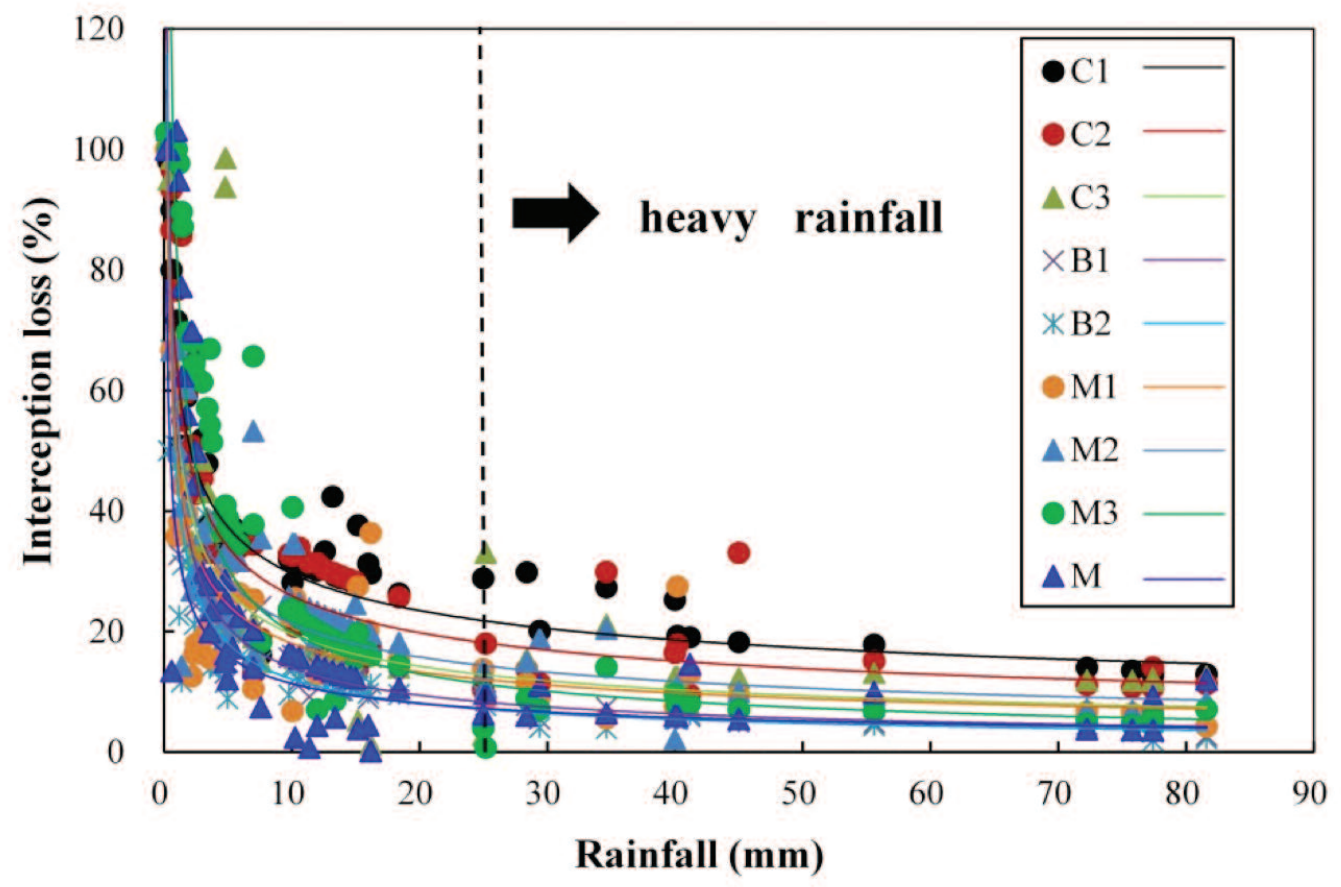

Fig. 7 The relationship between interception loss (\%) and rainfall amount.

interception loss for drizzle rainfall (Class I) and rainstorm (Class IV). In addition to the maximum rainfall frequency of drizzle rainfall (51.5\%) and the maximum cumulative amount of rain in the rainstorm event (40.5\%) (Table 4), the uniform angle index was closely correlated to the total accumulative interception loss (Fig. 4). This implies that an evenly distribution pattern is associated with a uniform canopy which generates less throughfall and stemflow, and results in an increase in interception loss.

\section{Conclusions}

Quantifying the effect of forest stand structure on rainfall partitioning is of considerable importance for forest hydrology. A focus is the impact of stand structure on rainfall partitioning, considering rainfall conditions. In this paper, the effects of non-spatial and spatial structure parameters of nine forest stands on rainfall partitioning were analyzed by 66 rainfall events. The results indicate that the effects of stand structure on throughfall, stemflow and interception loss vary greatly under different rainfall conditions. Leaf area index (LAI) is associated with interception loss for heavy rainstorms. The mingling index affects throughfall and interception loss for light rainfall, and a uniform angle index can affect interception loss for both light and heavy rainfalls. Stand structure, in combination with rainfall patterns, influences rainfall partitioning.

This research may enhance understanding of relationships between spatial structure of forest stands and rainfall partitioning. For all rainfall classes, the mingling index was negatively related to stemflow, while the uniform angle index was positively related. In addition to leaf and branch characteris- tics, the mingling patterns of different tree species and the spatial distribution of tree positions related to spatial structure should be included in future studies to better simulate interception and calculate water budgets.

\section{Acknowledgements}

This research was funded by the National Key Research and Development Program of China (2017YFC0505602) and the National Natural Science Foundation of China (No. 51309006).

\section{References}

Bosch, J. and J.D. Hewlett. 1982. A review of catchment experiments to determine the effects of vegetation changes on water yield and evapotranspiration. J. Hydrol. 55: 3-23.

Carlyle-Moses, D.E. and J.H. Gash. 2011. Rainfall interception loss by forest canopies. In: Forest Hydrology and Biogeochemistry, pp. 407-423. Springer Netherlands.

Carlyle-Moses, D.E., J.F. Laureano and A.G. Price. 2004. Throughfall and throughfall spatial variability in Madrean oak forest communities of northeastern Mexico. J. Hydrol. 297(1): 124-135.

Carlyle-Moses, D.E., C.E. Lishman and A.J. McKee. 2014. A preliminary evaluation of throughfall sampling techniques in a mature coniferous forest. J. Forestry Res. 25(2): 407-413.

Crockford, R.H. and D.P. Richardson. 2000. Partitioning of rainfall into throughfall, stemflow and interception: Effect of forest type, ground cover and climate. Hydrol. Process 14(16-17): 2903-2920.

Cui, Q.W., L.G. Bian and J.D. Shi. 1980. Effects of canopy on precipitation interception. Sci. Sinica 16(2): 144-146.

Dietz, J., D. Hölscher and C. Leuschner. 2006. Rainfall partitioning in relation to forest structure in differently managed montane forest stands in Central Sulawesi, Indonesia. Forest Ecol. Manag. 237(1): $170-178$. 
Dolman, A.J. 1987. Summer and winter rainfall interception in an oak forest: Predictions with an analytical and a numerical simulation model. J. Hydrol. 90(1-2): 1-9.

Dunkerley, D. 2000. Measuring interception loss and canopy storage in dry land vegetation: A brief review and evaluation of available research strategies. Hydrol. Process 14(4): 669-678.

Gadow, K.V. and G.Y. Hui. 2002. Characterizing forest spatial structure and diversity. In: Proc. of the SUFOR international workshop: Sustainable forestry in temperate regions (pp: 20-30).

Gadow, K. and K. Füldner. 1992. Zur Methodik der Bestandesbeschreibung. Vortrag anlaesslich der Jahrestagung der AG Forsteinrichtung in Klieken b. Dessau.

Hölscher, D., J. Mackensen and J.M. Roberts. 2005. Forest recovery in the humid tropics: Changes in vegetation structure, nutrient pools and the hydrological cycle. Forests, Water and People in the Humid Tropics, Cambridge University Press, Cambridge. pp. 598-621.

Inoue, A., M. Nagano and K. Sankoda. 2017. Rainfall interception in an intensively managed low density stand of bamboo, Phyllostachys pubescens. J. Forest Res. 22(1): 53-60.

Levia, D.F. and E.E. Frost. 2003. A review and evaluation of stemflow literature in the hydrologic and biogeochemical cycles of forested and agricultural ecosystems. J. Hydrol. 274(1): 1-29.

Levia, D.F., B. Michalzik and K. Näthe. 2015. Differential stemflow yield from European beech saplings: The role of individual canopy structure metrics. Hydrol. Process. 29(1): 43-51.

Liang, W.L., K.I. Kosugi and T. Mizuyama. 2011. Soil water dynamics around a tree on a hillslope with or without rainwater supplied by stemflow. Water Resour. Res. 47(2): W02541, Doi:10.1029/2010WR009856.

Li, X., J. Niu, L. Zhang, Q. Xiao, G.E. McPherson, N. van Doorn and C. Meng. 2016a. A study on crown interception with four dominant tree species: A direct measurement. Hydrol. Res. 47(4): $857-868$

Li, X., Q. Xiao, J. Niu, S. Dymond, N.S. van Doorn, X. Yu and J. Li. 2016b. Process-based rainfall interception by small trees in Northern China: The effect of rainfall traits and crown structure characteristics. Agr. Forest Meteorol. 218: 65-73.

Li, Y., T. Cai, X. Man, H. Sheng and C. Ju. 2015. Canopy interception loss in a Pinus sylvestris var. mongolica forest of Northeast China. J. Arid Land 7(6): 831-840.

Llorens, P. and F. Domingo. 2007. Rainfall partitioning by vegetation under Mediterranean conditions. A review of studies in Europe. J. Hydrol. 335(1): 37-54.

Loustau, D., P. Berbigier, A. Granier and F.E.H. Moussa. 1992. Interception loss, throughfall and stemflow in a maritime pine stand. I. Variability of throughfall and stemflow beneath the pine canopy. J. Hydrol. 138(3-4): 449-467.

Molina, A.J. and A.D. Del Campo. 2012. The effects of experimental thinning on throughfall and stemflow: A contribution towards hydrology-oriented silviculture in Aleppo pine plantations. Forest Ecol. Manag. 269: 206-213.

Park, A. and J.L. Cameron. 2008. The influence of canopy traits on throughfall and stemflow in five tropical trees growing in a Panamanian plantation. Forest Ecol. Manag. 255(5): 1915-1925.

Peng, H., C. Zhao, Z. Feng, Z Xu, C. Wang and Y. Zhao. 2014. Canopy interception by a spruce forest in the upper reaches of Heihe River basin, Northwestern China. Hydrol. Process. 28(4): 1734-1741.
Pérez-Suárez, M., J.T. Arredondo-Moreno, E. Huber-Sannwald and A. Serna-Pérez. 2014. Forest structure, species traits and rain characteristics influences on horizontal and vertical rainfall partitioning in a semiarid pine-oak forest from Central Mexico. Ecohydrol. 7(2): 532-543.

Ponette-González, A.G., K.C. Weathers and L.M. Curran. 2010. Water inputs across a tropical montane landscape in Veracruz, Mexico: Synergistic effects of land cover, rain and fog seasonality, and interannual precipitation variability. Glob. Change Biol. 16(3): 946-963.

Rodrigo, A. and A. Âvila. 2001. Influence of sampling size in the estimation of mean throughfall in two Mediterranean holm oak forests. J. Hydrol. 243(3-4): 216-227.

Roth, B. E., K.C. Slatton and M.J. Cohen. 2007. On the potential for high-resolution Lidar to improve rainfall interception estimates in forest ecosystems. Front. Ecol. Environ. 5(8): 421-428.

Rowe, L.K. 1983. Rainfall interception by an evergreen beech forest, Nelson, New Zealand. J. Hydrol. 66(1-4): 143-158.

Shinohara,Y., H. Komatsu, K. Kuramoto and K. Otsuki. 2013. Characteristics of canopy interception loss in moso bamboo forests of Japan. Hydrol. Process. 27(14): 2041-2047.

Staelens, J., A. De Schrijver, K. Verheyen and N.E. Verhoest. 2006. Spatial variability and temporal stability of throughfall deposition under beech (Fagus sylvatica L.) in relationship to canopy structure. Environ. Pollut. 142(2): 254-263.

Staelens, J., A. De Schrijver, K. Verheyen and N.E. Verhoest. 2008. Rainfall partitioning into throughfall, stemflow, and interception within a single beech (Fagus sylvatica L.) canopy: Influence of foliation, rain event characteristics, and meteorology. Hydrol. Process. 22(1): 33-45.

Tanaka, N., D. Levia, Y. Igarashi, N. Yoshifuji, K. Tanaka, C. Tantasirin and T.O. Kumagai. 2017. What factors are most influential in governing stemflow production from plantation-grown teak trees? J. Hydrol. 544: 10-20.

Teale, N.G., H. Mahan, S. Bleakney, A. Berger, N. Shibley, O.W. Frauenfeld and R. Washington-Allen. 2014. Impacts of vegetation and precipitation on throughfall heterogeneity in a tropical premontane transitional cloud forest. Biotropica 46(6): 667-676.

Tian, F., C. Zhao, Z. Feng, S. Peng and H. Peng. 2012. Eco-hydrological effects of Qinghai spruce (Picea crassifolia) canopy and its influence factors in the Qilian Mountains. Acta Ecologica Sinica 32(4): 1066-1076.

Xiao, Q., E.G. McPherson, S.L. Ustin, M.E. Grismer and J.R. Simpson. 2000. Winter rainfall interception by two mature opengrown trees in Davis, California. Hydrol. Process. 14 (4): 763-784. Zhao, Y., K. Wang, Q. Chen, Y. Wang, Y. Wang and X. Duan. 2012. Spatial structure characteristics of Pinus massoniana and broadleaved tree mixed forest in Jinyunshan National Nature Reserve in Chongqing City. For. Resour. Manag. 1: 48-53.

Zimmermann, A., W. Wilcke and H. Elsenbeer. 2007. Spatial and temporal patterns of throughfall quantity and quality in a tropical montane forest in Ecuador. J. Hydrol. 343(1): 80-96.

Zimmermann, B., A. Zimmermann, H.L. Scheckenbach, T. Schmid, J.S. Hall and M. van Breugel. 2013. Changes in rainfall interception along a secondary forest succession gradient in lowland Panama. Hydrol. Earth Syst. Sci. 17(11): 4659-4670. 